\title{
FINDING RELATIONSHIP TENDENCY IN ATTACK ON TITAN: LEVI AND ERWIN
}

\author{
Kamila Yasmine Kusuma', Bening Salsa Biela ${ }^{2}$, Vilya Lakstian Catra Mulia ${ }^{3}$ \\ ${ }^{1,2}$ IAIN Surakarta, Sastra Inggris, Fakultas Adab dan Bahasa, Jl. Pandawa, Kartasura, Sukoharjo, \\ Jawa Tengah, Indonesia, ${ }^{3}$ Politeknik Harapan Bangsa Surakarta, Program Studi Bahasa Inggris, Jl. \\ Ir. Sutami 46, Jebres, Surakarta, Jawa Tengah, Indonesia \\ kjasmine.szz@gmail.com ${ }^{1}$, beningsalsabiela@gmail.com ${ }^{2}$, vilyalakstian@gmail.com ${ }^{3}$
}

\begin{abstract}
As a popular manga series, Attack on Titan has various characters giving certain impression among the fandom. Two of them are Erwin Smith and Levi Ackerman. Erwin is known as an integrated and influencing commander meanwhile Levi is the humanity's strongest soldier who is also recognized as one of Erwin's closest subordinates. Their togetherness presents questions from the manga fans whether there is special relationship between them. Some fans accepted. However, there are not a few fans refused. Using systemic functional linguistics approach, the researchers try to reveal the happening tendency considering the clauses expressed by these two characters. Doing descriptive qualitative research, tenor analysis is done in the level of grammar. The researchers use criterion-based purposive sampling to get relevant data and process them from domain, taxonomy, componential, up to getting cultural theme analysis in order to get the impacts of language expressed by the characters in building tenor. The discussion shows complex interpersonal relationship because of considering the linguistic data findings along with their impacts towards the built social indication. The relationship tendency is taken from the features classified in status, affect, and contact. Those features reflect domination background, emotional state, and degree of formality. This research gives new perspective for language study towards debatable thing between factions carrying particular ideology.
\end{abstract}

Keywords: Grammar; Interpersonal Relationship; Manga; Tendency; Tenor Analysis

\begin{abstract}
ABSTRAK
Sebagai serial manga populer, Attack on Titan memiliki beragam tokoh yang memberikan kesan tersendiri di hati pembacanya. Dua di antaranya adalah Erwin Smith dan Levi Ackerman. Erwin dikenal sebagai komandan yang terintegrasi dan berpengaruh, sedangkan Levi adalah prajurit terkuat umat manusia yang juga diakui sebagai salah satu bawahan terdekat Erwin. Kebersamaan mereka menimbulkan tanda tanya dari penggemar manga ini apakah terdapat hubungan khusus di antara mereka. Beberapa penggemar menyetujui, namun tidak sedikit yang menolaknya. Menggunakan pendekatan linguistik sistemik fungsional, peneliti berusaha mengungkap kecenderungan yang terjadi melihat klausa yang diungkapkan oleh kedua tokoh. Menjalankan penelitian kualitatif deskriptif, analisis tenor dilakukan pada tingkat tata bahasa. Peneliti menggunakan purposive sampling dengan berbasis kriteria untuk memperoleh data yang relevan dan mengolahnya mulai analisis domain, taksonomi, komponensial, hingga memperoleh analisis tema budaya untuk mendapatkan dampak dari bahasa yang diekspresikan kedua tokoh dalam membangun tenor. Pembahasan menunjukkan hubungan interpersonal yang kompleks karena mempertimbangkan temuan data linguistik beserta dampaknya terhadap indikasi sosial yang dibangun. Kecenderungan hubungan itu diperoleh dari ciriciri yang diklasifikasikan dalam status, afek, dan kontak. Beragam ciri itu menggambarkan latarbelakang dominasi, keadaan emosi, dan tingkat keformalan. Penelitian ini memberikan pandangan yang baru pada kajian bahasa terhadap sesuatu yang menjadi perdebatan antar kelompok dengan bawaan ideologi tertentu.
\end{abstract}

Kata kunci: Tata Bahasa; Hubungan Interpersonal; Manga; Kecenderungan; Analisis Tenor. 


\section{INTRODUCTION}

Comics are "a sequence of separate images" with "a preponderance of image over text" that appears in "a mass medium" and tells "a story which is both moral and topical (Kunzle, 2015). Comics deal with two major communicating devices: words and images (Eisner, 1985). Although, the two devices tend to treated separately, in the modern times, they become one independent discipline and continue to develop more creatively.

Poitras defined manga as a Japanese comic book published by Japanese publishers for Japanese audience. Its characteristics are more complex compared to American comics and has numerous variation of fiction, non-fiction, and prose (MacWilliams, 2008). Whereas "manhwa" is the term for comic in Korea (Yoon, 2001) and "manhua" is commonly used to denote the term comic in China.

A social text analysis aims to describe the life-world within which the text is inserted to reveal the author's perspective which is defined by his/her social and cultural context and to draw attention to the structural feature of everyday practices and meaning designs (Bauer et al., 2014). Furthermore, among functional linguistics, systemic functional linguistics used to analyze the text has been designed to investigate the interrelationships reflected in proportionalities of this kind (Martin, 1992).

As a part of systemic functional linguistics concern, tenor analysis is applicable in text analysis since it digs context of situation for interpersonal meaning which becomes the main focus of this research. Since tenor is the negotiation of social relationships among participants (Martin, 1992), the interpersonal meaning is realized primarily through the interpersonal metafunction in language.

Analyzing clause in fiction had attracted some researchers such as Koussouhon and Tchibozo-Laine (2016), Yuliana (2017), and Uswar, Yenita, and Andriani (2020) to use mood structure to get interpersonal meaning. Uswar, Yenita., and Andriani (2020) got the text goal implemented in Tale's Story of Sabai Nan Aluih. Yuliana (2017) got the realization of interpersonal meaning in Islamic academic institutions course newsletters. Whereas Koussouhon and Tchibozo-Laine (2016) got advancement by including tenor analysis to support feminist approach in the study in Amma Darko's Beyond the Horizon, The Housemaid, and Faceless. In addition, Huabin (2018) analyzed code switching to get the interpersonal meaning in the I Not Stupid, Moonlight Resonance, and Humble Abode TV series.

This research uses tenor analysis for finding tendency of fans' interpretation that relates to the story and reveals it by using linguistic proofs. This way will improve Koussouhon and Tchibozo-Laine (2016), Yuliana (2017), Uswar, Yenita. and Andriani (2020), and Huabin (2018) to have linguistic proofs up to finding ideological tendency.

Japan successfully creates a huge explosion to increase the popularity of its products, manga. Among various manga genres and titles, we decided to choose 
Attack on Titan manga series to be discussed in this paper. Attack on Titan is illustrated by Isayama and is published by Kodansha. The manga has sold over 100 million copies worldwide as of December 2019, allowing it to become one of the best-selling manga series in history.

Some reviews from fans revealed that the unusual features, unexceptional plot, and strong characters in the manga makes the popularity of the series last long. Whilst characters are often mentioned, there are at least three main characters in this series namely Jeager, Ackerman, and Arlert. Some supporting characters also leave certain impression among fans, such as Erwin Smith and Levi Ackerman.

The opinions on the unsolved questions, plot, characters, and interpretations are what we can easily find on the web. The one from so many famous topics of interpretation is pairing of the characters. Pairings are also known as ship. Attack on Titan has several pairings, and one character can be paired to several other characters, not just one. It could be a slash (same gender) pairing too, such as Erwin and Levi (EruRi). This pairing stuff solely depends on reader's preference.

In fact, even if pairing is not the dominant thing in the series, the fandom can still argue with each other just to defend their ship. This also happens to the EruRi pairing which has been officially published in the Shipping Fandom webpage along with explanations and supporting background behind it. Shipping Fandom is a subweb of Fandom, also known as Wikia; a wiki hosting service and domain operated by Fandom, Inc. Company. Founded in October 2004 by Jimmy Wales and Angela Beesley, it has several media licensing, such as Creative Commons Attribution/ShareAlike 3.0, makes it a reliable source for the fandom. Some fans are shipping the two because of their long history together, which has resulted in a deep personal connection. While there have been some acknowledgements, there exist the group who disagree. Their main reason is that Erwin Smith and Levi Ackerman should only have respected each other and has platonic relationship.

Given these two contradicting opinions, the researchers decided to conduct a research regarding EruRi pairing using the functional grammar approach, which allows us to do tenor analysis as the way of interpreting the characters in order to recognize their tendency: having romantic relationship or not. Tenor is described as who is taking part in the situation: the roles played by those taking part in the sociosemiotic activity and the values that the interactants imbue the domain with (either neutral or loaded, positively or negatively (Halliday \& Matthiessen, 2014). The analysis is done on the level of grammar by analyzing the status, contact, and affect as seen from their utterances in Attack on Titan volume 13 to 18.

\section{LITERATURE REVIEW}

Context is where language functioning through text (Halliday \& Matthiessen, 2014 , p. 3). It was extended to things other than language in the nineteenth century, 
but if we were discussing language, it is still referred to the surrounding words. Text is semantic tool in social context, thus it needs to be contextualized in any comprehensive model of a culture's text forming resources. The term 'context of situation' then appeared and it has tenor as one of its components.

Tenor indicates the negotiation of social relationships between participants (Martin, 1992). Tenor puts significant phonological and lexicogrammatical systems such as tone, mood, key, polarity, modalization, modulation, comment, tagging, vocation, person, and various attitudinal systems across ranks and permeating lexis at risk, as well as a negotiation framework at the level of discourse analysis. It is concerned with the semiotics of relationships and mediates these relationships through three dimensions: status, contact, and affect.

Status is referred to the relative position of interlocutors in a culture's social hierarchy (Martin, 1992). The key principle of status is reciprocity of choice: equal status among participants is realized if they are taking the same kinds of options, while the status is unequal if they are taking different choices. The distinction among dominance and deference is made in order to explore the realization of status in the context of unequal status between interlocutors. In the level of grammar, dominance is indicated by the presence of no ellipsis, polarity asserted, high modalization, modulation (obligation), manifested attitude, presented comment, familiar vocation, first person, inviting tags, or 'I' as agent. Meanwhile, the deference is indicated by the existence of residue ellipsis, polarity matched, low modalization, modulation (inclination), concur attitude, invited comment, respectful vocation, second person, checking tags, or ' $\mathrm{I}$ ' as medium.

Contact means the degree of institutional involvement with each other and it is concerned with the degree of involvement among interlocutors (Martin, 1992). The nature of fields in which the speaker/listeners are participating, how much contact is involved, how regularly whether work or leisure determine the contact. Less contact indicates that the realization of meanings selected has to be more explicit. Meanwhile, more contact is assumed that more information could just be left untold. A participant is considered having involved contact by minor clauses, mood ellipsis, mood contraction, vocation, range of names, or nick-name. However, major clauses, no ellipsis, no contraction, no vocation, single name, or full name will indicate a participant as uninvolved role in the conversation. Halliday describes affect as the degree of emotional charge in the relationship among participants. The basic principle of affect is amplification, making something more intense. In the level of grammar, several aspects of the realization of affect can be shown through exclamative, attitude, comment, minor expressive, intensification, repetition, prosodic nominal groups, diminuitives, mental affection, or manner degree. 


\section{RESEARCH METHOD}

This research applies qualitative research along with its treatment on language unit as data in the level of clause from the utterances expressed by the characters. This research describes tenor analysis by Martin (1992, pp. 523-535) towards the data. This way is relevant with the research paradigm as Sutopo (2006, p. 40) saying qualitative research concerns on describing its relevant data like words and clauses. The data of the research are clauses with their words. It relates to the implementation of tenor analysis in the level of grammar. SFL takes lexicogrammar to do this practice towards the combination of grammar and lexis to get meanings (Matthiessen et al., 2010, p. 131).

The researchers take discourse analysis on the comic entitled Attack on Titan by (Isayama, 2009) as the data source. To conduct the analysis, the researchers apply purposive sampling to get relevant data that are fit with this research's need. The data are taken by fulfilling these criteria:

a. The data are clauses. If there is sentence, it must be checked whether containing complex clauses. When this case is found, the researchers divide the sentence into clauses.

b. Major clause shows when there is mood element $S^{\wedge} F$ in declarative, $F$ in imperative, and $\mathrm{WH}^{\wedge} \mathrm{F}^{\wedge} \mathrm{S}$ or $\mathrm{F}^{\wedge} \mathrm{S}$ in interrogative clause (Halliday \& Matthiessen, 2014, p. 162).

c. Minor clauses are taken as data because Martin (1992, p. 532) considers them for analyzing contact in tenor analysis.

d. The criteria (a) and (b) are expressed by the character named Levi and/or Erwin in the comic entitled Attack on Titan volume 13 up to 18 telling about the humanity war against titan creatures.

The criteria above guide the researchers to get relevant data for tenor analysis in the level of grammar. They are formulated to have discourse analysis that has goal to understand how communication does language practice, in this context is in written mode. Heigham \& Croker (2009, p. 244) emphasize this way for describing internal relationship of form and meaning.

For getting data validation, the researchers work on source triangulation by using two kinds. They are the comic and the fandoms expressing their theories of Levi and Erwin. The comic identity has been described on the criterion (d). The fandoms' are taken from Shipping Fandom Website and one of a fan-blogs namely WirSindDieRanters (on Tumblr) which has most number of shares and likes.

This research has main goal to get linguistic proof in finding tendency by the characters that are fit with which of the proposed theories by their fans. In order to get the proof, the researchers conduct data analysis technique by Spradley (2007). First, the researchers get the data and eliminate those that are not classified as required data. This way is underlay by the criteria (a) to (d) above. After getting the data, taxonomy analysis is done by taking the data into the classification towards grammar 
characteristics in status, contact, and affect (see the total data as shown in Table 1). To get componential analysis, the researchers connect the tenor analysis (see Table 2 and Picture 1) with the proposed theories by the fandoms. The correlation between them is finally interpreted by finding connection from the componential analysis for getting cultural theme (the details on wording the discussion and drawing conclusion).

\section{FINDING AND DISCUSSION}

\section{Finding}

Interaction is the collaborative exchange of thoughts, feelings, or ideas between two or more people, resulting in a reciprocal effect on each other (Brown, 2001). In fiction texts such as novel and comic, the characters are doing interaction. All those interactions happen in the plot of the story. Since those interactions mostly consist of language exchange, it is important to know overall language activities which interpersonally built in the story.

\section{Interpersonal Situation in the Story}

Table 1 below shows interpersonal implementation generally happened between the characters. It is a good start to have a glance of interpersonal language practices happening in the plot.

Table 1. Interpersonal Implementation by the characters

\begin{tabular}{|c|c|c|c|c|}
\hline \multicolumn{2}{|c|}{ Status } & \multicolumn{2}{c|}{ Contact } & \multirow{2}{*}{ Affect } \\
\cline { 1 - 4 } Dominate & Defer & Involved & Uninvolved & \\
\hline $82.30 \%$ & $17.70 \%$ & $19.90 \%$ & $80.10 \%$ & $29.1 \%$ \\
\hline
\end{tabular}

Status refers to the position of the speaker and his or her interlocutor in a culture's social scale. It is closely related to the concept of power between the characters and divided into dominate and defer, whereas contact refers to the institutional participation degree. On the other hand, affect is the degree of emotional charge within the participants' relationship (Martin, 1992). The researchers count the checked marks on the characteristics of dominate and defer towards the expressed clauses by Levi and Erwin. Table 1 shows that there is domination implied from the clauses. In contact, the characters mainly practice formality. The number of affect is taken by counting the existence of words signaling emotion compared with the total clauses. This general finding needs to be crosschecked with interpersonal meanings uttered by each character.

Martin (1992) formulated the characteristics of tenor as listed for status, contact, and affect. The clause needs to be counted for showing whether a character dominates in status (see Status A) and is involved in contact (see Contact A) by paying attention on the high number of occurrence in particular classification. 
However, there are some clauses that are same in number on both parts in status (see Status B) and contact (see Contact B). This makes expressed clause tend to be neutral because there is less domination.

The researchers have collected all clauses from Erwin Smith and Levi Ackerman, categorized them according to their characteristics, and concluded the results as depicted in the table below.

Table 2. The comparison of tenor's clause characteristic findings

\begin{tabular}{|l|c|c|c|c|c|c|c|c|c|}
\hline \multirow{2}{*}{ Character } & \multicolumn{2}{|c|}{ Status A } & \multicolumn{2}{c|}{ Contact A } & \multicolumn{2}{c|}{ Status B } & \multicolumn{2}{c|}{ Contact B } & \multirow{2}{*}{ TOTAL } \\
\cline { 2 - 10 } & Dm & Df & In & Un & Dm & Df & In & Un & \\
\hline Levi & 291 & 49 & 101 & 412 & 19 & 19 & 5 & 5 & 901 \\
\hline Erwin & 259 & 43 & 69 & 287 & 14 & 14 & 0 & 0 & 686 \\
\hline TOTAL & 550 & 92 & 170 & 699 & 33 & 33 & 5 & 5 & 1587 \\
\hline
\end{tabular}

The examples below display the clauses that have different numbers between the classifications. The clause (1) makes Erwin's utterance gets power for interpreting status. On the other hand, there are more labels for the clause (2). The labels for uninvolved contact are more than involved that makes the clause sound formal in interpreting contact.

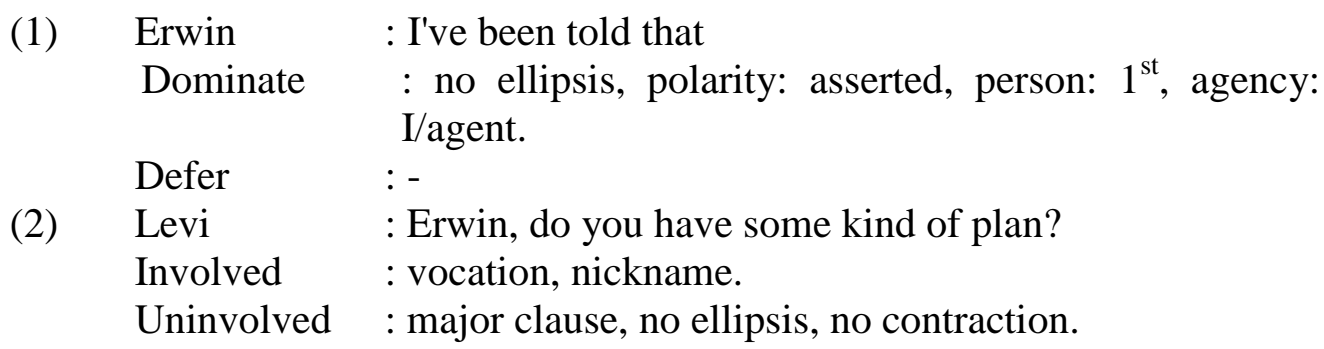

In several conditions, clauses may have same number to make them fulfill both classifications. The examples show such condition that cannot be left. The clause with this condition remains contributing interpersonal meaning because it presents communicative session between speakers. The clause (3) signals it more equal because it contains same number in both classifications. The clause (4) does same for contact.

(3) Erwin : You may be able to defeat the beast.

Dominate : no ellipsis, polarity: asserted

Defer : modalization: low, person: $2^{\text {nd }}$

(4) Levi : More than humanity's victory?

Involved : minor clauses, mood ellipsis

Uninvolved : no contraction, no vocation 
The clause (3) and (4) are the examples when the quality of status and contact can be termed "balanced" because they carry same amounts in their tenor characteristics and nothing is heavy-side. With their numbers, Status B and Contact B may not contribute much on building domination and formality in this plot.

Table 2 arises interpretation because of the dominance of particular parts. Levi Ackerman has more expressed clause in Status A compared to Erwin Smith. This finding indicates that Levi is dominant in the communication between the two and normally, the dominance in expressed clauses indicates that one has higher status or bigger power. However, Levi is Erwin's subordinate so it is impractical to say that Levi has more power than Erwin does. Throughout the story, Erwin is portrayed as a leader who listens to his comrades and takes a good care of them equally which makes it reasonable if Erwin speaks less than he should have been. Also, the fact that Levi is one of Erwin's closest subordinates strengthens the assumption that Erwin actually lets Levi be dominant in their communication. On the other hand, Status B does not give significant change to Status A. It only contributes $9.3 \%$ of total findings while compared with unequal status shown in Status A dominating in $90.7 \%$ of the total findings in this research.

In Contact A, Levi shows his dominance than Erwin does. The dominance in involved contact indicates that sometimes, Levi speaks casually to Erwin. The high number applies to uninvolved contact in which Levi speaks formally to Erwin. This way is supported by his role as a subordinate. These two contact findings implied that Levi actually tries to be close to Erwin but cannot do much because of the different hierarchical status. The comparison of uninvolved and involved contacts by Levi show possible interpretation that he has tendency have attention with Erwin. The researchers can only say this as "tendency". This interpretation arouses because his utterances are dominantly formal (counted 412 findings) and less than a half indicating being informal. Erwin remains positioning him as respected person. Being cool, he is characterized as a thinker and attracted-to-listen person. The other part of tenor analysis is by finding affect in order to get how much emotion is expressed. This analysis is required to know how someone reacts to person or thing that is practiced in his sayings.

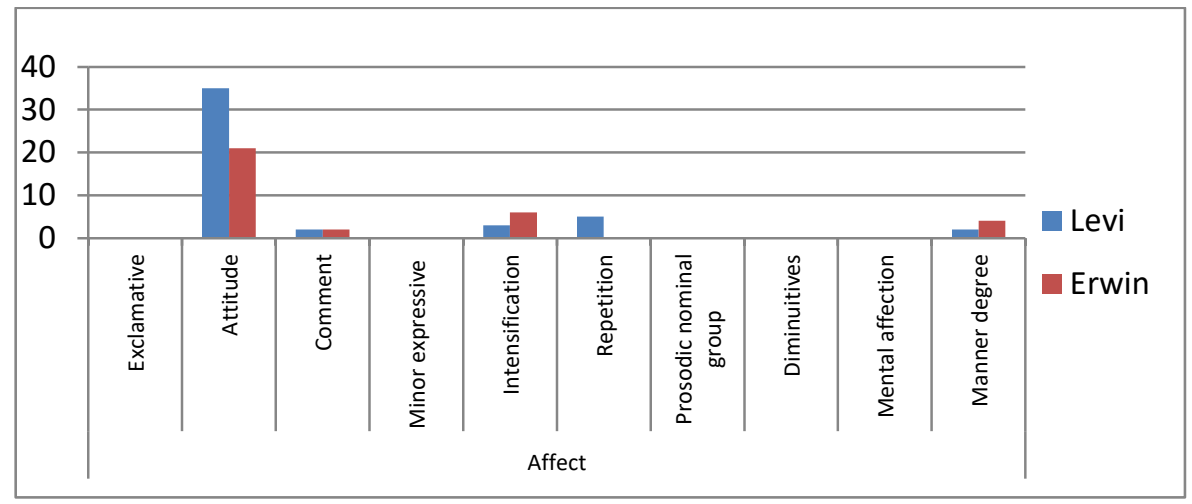

Picture 1. Emotions expressed by the characters 
Picture 1 shows that the emotions are reflected in words indicating attitude, comment, intensification, and manner degree. In many times, Levi shows more utterances which indicate attitude compared to Erwin's.

(5) Levi : I'm sorry, Erwin

Affect : attitude

(6) Levi : Honestly, I'm not expecting anyone to make it home alive at this point.

Affect : comment

(7) Erwin : We've taken massive losses

Affect : intensification

(8) Erwin : Without me, it's less likely to succeed.

Affect : manner degree

The clause (5) shows emotion by expressing attitudinal words. These words can be positive and negative. The other attitudinal words such as better, right, sorry, bad, ugly, doubt, not true, and so on. The clause (6) displays how word can imply comment like expressing comment adjunct. It is natural that character in a story expresses his feeling towards person or thing that is different than what he thought before like presented in the clause (7). Intensification can be pushed up or down. Erwin tends to express intensification such as uttering the word very and quite. He also uses more manner degree such as likely, nearly, and surely compared to Levi. One of them is displayed on (8).

\section{Discussion}

The findings above contribute the basis of finding relationship between Levi and Erwin that remain being debated among their fans. As long as they communicate, this curiosity can be tracked in language by text analysis.

\section{Character's Emotional State}

The finding displaying change in personality (see Picture 1) arise question towards their emotion. Erwin who has position institutionally higher than Levi expresses less in attitude, but more in intensification. Although the change is not really significant, this finding can indicate Levi's sensitivity and emotional character especially when compared to Erwin's who is a lot calmer since he expresses less attitude in his utterances. Erwin's utterances that contain manner degree indicate his insecurity that refers to battle conditions.

\section{The Existence of Monologue and Its Influence}

The author of Attack on Titan manga series, Hajime Isayama, plays a prominent role in building the relationship between Levi Ackerman and Erwin Smith. As what has been mentioned in the discussion above, Levi dominates both in status and contact. In the context of status, Levi gets his high position than Erwin to 
dominate. This finding is quite surprising with his subordinate.

When the researchers recheck their data, this is affected by his monologue like the following.

"What? You want me to approach the beast by myself using vertical maneuvering? There's nothing around him! There isn't a single tree or house or anything else I can use! No, you have targets that are the perfect height. They're standing there all in a row, aren't they? Use the titans to sneak up on and ambush the beast titan."

The monologue above happens in chapter 80 . The other appears in chapter 81 . This monologue is a testament to the clause that Levi's mind passed to his commander, Erwin. In chapter 80, Levi takes Erwin's action. In addition, chapter 81 shows that Levi thinks about the possibility of Erwin surviving even though it is almost certain that he is dying and will die. In terms of status, these monologues contributed to this excess. If we exclude the monologues, the linguistic proof will be relevant to the position that Levi serves with Erwin. Levi's monologues are considered as the data because they are uttered for Erwin's behavior and condition. When the monologues are left, Levi and Erwin's comparison is 217:259. The status position is then changed, but this finding remains meaningful. Erwin lets his subordinate speak and listens to him carefully.

\section{Considering Degree of Formality}

Contact dominance shows that Levi tries to be close without crossing the line (in this case, their hierarchical status in the organization). This interpretation is taken from the finding displaying Levi's high number in uninvolved contact. As subordinate, he respects Erwin by practicing formality. Then, in some moments, he speaks informally as shown in his involved contact.

\section{Linguistic Findings and Official Statement}

Levi's tendency to have attention with Erwin is supported with this statement from a Japanese director, Tetsuro Araki:

Interviewer : "I would like to ask about Levi and Erwin's relationship. Can we call their relationship 'friendship'?"

Tetsuro Araki : "I think you can say it's friendship. But of course there is emotion between them which cannot be concluded as 'friendship'."

(Taken from the official's "EruRi," n.d quoting Animedia in April, 2019)

The clauses which indicate Levi's sensitivity and Erwin's decisiveness and insecurity arises possible interpretations. Since there is no clause which indicates mental affection such as love, like, hate, and so on, the researcher cannot directly say that both of the characters are in a romantic relationship. However, if there is a tendency to say so, this relationship may be expressed explicitly which cannot be properly seen due to the limitation of context and linguistic proofs which require 
multidisciplinary approach. It is interpretable, if the author designed these characters have more than friendship, the communication built between them is succeed to be presented indirectly so that some readers have not realized yet. This may cause the debate between those two fan-factions.

\section{CONCLUSION}

This research uses tenor analysis, a part of systemic functional linguistics which is relevant to find the interpersonal meaning, particularly the tendency of fans' interpretations related to the story of Attack on Titan by using linguistic proofs. This research answers the question which has been raising many interpretations among the fans about the possibility of Levi Ackerman and Erwin Smith's romantic relationship. The analyses are in the level of grammar in describing communication built by these two characters. Based on the linguistic proofs analyzed with tenor analysis, there are two interpretations found in this research. First, it is found that Levi has tendency to have attention with Erwin. He is also revealed to be the dominant person in performing communication between them. Second, this research also found that both of the characters cannot be said to be in a romantic relationship since there is no clause uttered by them which indicates mental affection. Furthermore, this research is expected to trigger other scholars in doing research in developing relevant topic by employing more situation context and linguistic proofs in the story.

\section{BIBLIOGRAPHY}

Bauer, M. W., Bicquelet, A., \& Suerdem, A. K. (2014). Text Analysis: An Introductory Manifesto. In Textual Analysis. Sage Benchmarks in Social Research Methods, 1. SAGE Publisher Ltd. http://eprints.lse.ac.uk/57383/

Brown, D. (2001). Teaching by Principles (p. 480). Longman.

Eisner, W. (1985). Will-eisner-comics-and-sequential-art.pdf (p. 164). Poorhouse Press. Google Scholar

EruRi. (n.d.). Retrieved April 20, 2021, from https://shipping.fandom.com/wiki/EruRi

Halliday, M. A. K., \& Matthiessen, C. M. I. M. (2014). Halliday's Introduction to Functional Grammar. Routledge. Google Scholar

Heigham, J., \& Croker, R. A. (Eds.). (2009). Qualitative Research in Applied Linguistics. Palgrave Macmillan. Google Scholar

Huabin, W. (2018). Interpersonal Meaning of Code-Switching: An Analysis of Three TV Series. Australian Journal of Applied Linguistics, 1(1), 3-19. http://files.eric.ed.gov/fulltext/EJ1244878.pdf

Koussouhon, Léonard A., \&, \& Tchibozo-Laine, I. (2016). Tenor and Interpersonal 
Meaning in Amma Darko's Fiction: A Feminist Approach. Studies in English Language Teaching, 4(4), 650. https://doi.org/10.22158/selt.v4n4p650

Kunzle, D. (2015). Gustave doré. University Press of Missisipi. Google Scholar

MacWilliams. (2008). Japanese Visual Culture (Vol. 4, Issue 3). An East Gate Book. Google Scholar

Martin, J. R. (1992). English Text. John Benjamin Publishing Company. Google Scholar

Matthiessen, C. M. I. M., Teruya, K., \& Lam, M. (2010). Key Terms in Systematic Functional Linguistics. Continuum. Google Scholar

Spradley, J. P. (2007). Metode Etnografi. Tiara Wacana. Google Scholar

Sutopo, H. (2006). Metodologi Penelitian Kualitatif: Dasar Teori dan Penerapannya dalam Penelitian. Universitas Sebelas Maret. Google Scholar

Uswar, Yenita., \& Andriani, N. (2020). Interpersonal Meaning Analysis in the Tale' s Story of Sabai. Southeast Asia Language Teaching and Learning Journal, 3(2), 58-65. https://doi.org/10.35307/saltel.v3i2.57

Yoon, Y. (2001). A Study of the Development of Sunjong Manhwa. Yonsei University, 73. https://doi.org/10.14288/1.0090316

Yuliana, D. et al. (2017). The realization of interpersonal meaning in course newsletters: A systemic functional linguistic perspective The Realization Of Interpersonal Meaning In Course Newsletters: A Systemic Functional Linguistic Perspective. June. https://doi.org/10.17509/ijal.v7i1.6873 